\title{
TYPOLOGIES OF FREIGHT FORWARDING SERVICE FAILURES AND RECOVERY STRATEGIES
}

\author{
NAZLI GÜLFEM GIDENER ÖZAYDIN ${ }^{(1)}$, EZGi GÜÇLÜOĞULLARI(2), DURMUŞ ALi DEVECi(3)
}

\begin{abstract}
In broad terms, freight forwarders offer their customers certain logistics and shipping services. The customers who purchase these services are shippers, exporters and importers. The overall aim of the freight forwarders is to satisfy shippers, and thus sustain competitive advantages in the logistics industry. Shipper experience, dissatisfaction and complaints from freight forwarding services have not previously been studied to a greater degree in the literature. Business to business service quality research has grown as a result of increased attention to quality for shippers recently. The overall aim of this study is to analyze service failures encountered and service recovery strategies employed in freight forwarding industry. The analysis also covers the causes of such failures, the actions taken to recover service failures, and the effects of these actions on the relationship between the shippers and freight forwarders. In order to reach this aim, Critical Incidents Technique (CIT), a means of measuring the perceived service quality and service failures, is used. A total of 100 critical incidents; 50 from shippers and 50 from freight forwarders related to service failures and recoveries in the freight forwarding industry were analyzed.
\end{abstract}

The overall findings revealed that the most prevalent service failures in the forwarding industry from the viewpoint of shippers are related to documentation, information and communication, operations, equipment, booking, and delivery services. The result of the study also revealed that apologizing from shippers, compensating all losses and damages and paying back certain amount of freight costs are most often employed recovery methods against freight forwarding service failures, and about in one fourth of such cases the encounters are likely to weaken the relationship between shippers and freight forwarders. From the freight forwarder employees' point of view service failures are categorized into seven main groups: failures in operations, documentation, booking, information and communication, problem shippers, delivery and equipment. Service recovery strategies employed by the freight forwarders from the employees' point of view

1 Dr, Dokuz Eylül University, Maritime Faculty, Department of Logistics Management, ngg.ozaydin@deu.edu.tr

2 Seago Line, ezgi.gucluogullari@seagoline.com

3 Prof. Dr., Dokuz Eylül University, Maritime Faculty, Department of Maritime Business Administration 
are ranked as compensating all loses/damages, giving convincing explanations, changing suppliers and carriers, apologizing, correcting bill of lading and invoicing. Findings from the service employees' point of view also founded that one fifth of relations after the service failures and recovery strengthened the relations between the shipper and freight forwarder.

Keywords: Service Failures, Recovery Strategies, Freight Forwarding Services, Critical Incidents, Business to Business Services. 


\title{
NAVLUN SEVKIYATI HIZMET KUSURLARI VE GERI KAZANIM STRATEJILERININ TIPOLOJILERI
}

\begin{abstract}
Öz
Taşıma işleri komisyoncusu işletmeler, müşterilerine belirli lojistik ve deniz taşımacılığı hizmetleri sağlayan işletmelerdir. Bu hizmetleri satın alan müşteriler yükleten, ihracatçı ve ithalatçılardır. Taşıma işleri komisyoncularının genel amacı yükletenleri memnun ederek, lojistik sektöründe sürdürülebilir rekabetçi avantaj elde etmektir. Yükleten deneyimleri, taşıma işleri komisyoncusu ile ilgili memnuniyetsizlik ve şikayetleri daha önce literatürde pek geniş yer almamıştır. Bu tür çalışmalara olan ilgi, yükletenlerin kalite anlayışlarına olan ilginin artmasına bağlı olarak artmaktadır. Bu çalışmanın amacı taşıma işleri komisyoncularının ve müşterilerinin yaşadıkları hizmet hatalarını ve uygulanan telafi yöntemlerini analiz etmektir. Ek olarak, yaşanan hizmet hatalarının nedenleri, telafi için alınan önlemler ve bu önlemlerin yükleten ile taşıma işleri komisyoncusu arasındaki ilişkiye etkileri de çalışmada yer almaktadır. Bu amaçlara ulaşmak adına algılanan hizmet kalitesini ölçmek adına KOT (Kritik Olay Tekniği) kullanılmıştır. Toplamda, elli adet yükletenlerden, elli adet taşıma işleri komisyoncularından toplanmış olan 100 adet kritik olay analiz edilmiştir.
\end{abstract}

Bulgular ışığında, yükletenlerin bakış açısına göre en sık rastlanan hataların dokümantasyon, bilgilendirme ve iletişim, operasyon, ekipman, rezervasyon ve teslim hizmetlerinde yaşandığı belirlenmiştir. Ek olarak, yükletenlerden hata sonrasında özür dilemenin, tüm hasar ve zararı tazmin etmenin ve navlunun bir kısmını karşılamanın taşıma işleri komisyoncuları tarafindan en sık uygulanan telafi yöntemleri olduğu ve bu tür olaylar sonrasında dörtte bir oranla aradaki ilişkinin zayıfladığı ortaya çıkmıştır. Taşıma işleri komisyoncusu bakış açısına göre ise hatalar: operasyonel, dokümantasyon, rezervasyon, bilgi ve iletişim, yükletenlerle ilgili hatalar, ekipman ve teslim hataları olarak sınıflandırılmıştır. Taşıma işleri komisyoncusu bakış açısından en sık uygulanan telafi yöntemleri ise tüm zarar ve hasarın tazmin edilmesi, açıklama yapılması, tedarikçilerin değiştirilmesi, özür dileme, konşimento ve faturaların değiştirilmesi olarak sıralanmıştır. Taşıma işleri komisyoncularının bakış açısından ise yaşanan hizmet hatası ve uygulanan telafi stratejisi sonrası beşte bir oranla taşıma işleri komisyoncusu ve yükleten arasındaki ilişki kuvvetlenmiştir.

Anahtar Kelimeler: Hizmet Hataları, Telafi Stratejileri, Üçüncü Taraf Lojistik Hizmetler, Kritik Olaylar, İşlemeler arası Hizmetler. 


\section{Introduction}

Service failures and recovery strategies are frequently considered as an inevitable consequence of service provision (Hess et al., 2003) due to the simultaneity of production and consumption, and involvement of customers in the production of service. Since 1990s literature on services emphasizes the increasing need to analyze service failures, learn from service problems and increase the understanding of how service recovery strategies affects the company's overall business performance and its future relationships with their customers. Analyzing the service failures help determine the basic factors leading to the evaluation of the customers in terms of causing satisfaction or dissatisfaction. The service recovery research has been developing non- stop over the past 20 years with the rise of service economies and customer-focused strategies utilized by a growing number of companies (Johnston and Michel, 2008). The whole idea behind the importance of service failures and recovery strategies is their impact on the relationship between the company and its customers. Service failures may cause destabilization of long-term relationships causing customers to reconsider the relationship moving away from the business-as- usual mindset (van Doorn and Verhoef, 2008). Therefore, the careful examination of service failures and providing effective recovery strategies are highly significant for developing and improving relationships.

Although service failures and recovery strategies were studied in various business to consumer markets the literature on the service failures and recoveries in freight forwarding industry is limited. The level and the quality of the service customers receive have a huge impact on the company's ability to retain customers or even attracting new ones, therefore, any failure in logistics customer service and its effects on the overall perceptions of the customer should not be overlooked (Oflaç et al., 2012).

Service failures can arise anywhere and may be encountered even in the best of freight forwarding companies. Preventing occurrence of service failures and mistakes and developing the competence to recover in a professional manner is crucial for the success of the freight forwarding companies. Hence, the object of the study is freight forwarders. The freight forwarder is a third party logistics provider, also referred to multimodal transport operator. Forwarders generally do not own transport vehicles, they deal with various carriers transport mode operators and carriers in supply chain in providing logistics services. In broad terms, freight forwarders offer their customers certain logistics and shipping services. The customers who purchase these services are organizational buyers such as shippers, exporters and importers. The overall aim of the freight forwarders is to offer quality logistics services and satisfy shippers, and thus sustain competitive advantages in the logistics industry. Recently, freight forwarders are multifunction intermediary and organizer of logistics service, concerning not only selecting 
carrier, but also dealing with the customs, warehousing, documents handling, and other related issues before cargo was delivered to final destination. The main tasks of freight forwarder are arranging transportation, border crossing of cargoes, advising shipping solution and choosing the best shipping method and carrier, booking space from carrier, supervising loading/unloading, (de)consolidation of shipments. The services provided by each forwarder are various depending on the company size. In some cases, forwarder also acts as a carrier in part of the cargo movement (Kula Değirmenci, 2012:182).

The logistics service quality has been examined through reliability, timely responsiveness, accuracy in documentation, accuracy in information, service fulfillment, problem solving ability and empathy dimensions as well (Stewart, 1995; Beamon, 1999; Gunasekaran et al., 2001; Mentzer et al., 2001; Panayides and So, 2005). In addition, Bienstock et al., (1996) found out that the most important determinants of physical distribution are related with the timeliness and the availability of the service. Moreover, logistics specific service failures have been identified as: wrong delivery, lost shipments, documentation errors, communication problems, customs, stuffing, unloading, container tracking, port operations, quoting rates, booking, delay, damage, timeliness, financial, equipment (Deveci, 2002). Finally, it should be highlighted that, the occurrence of the service failure does not necessarily refer to logistics service provider's inadequacy; even the best of service providers makes mistakes and even flawless service is impossible the way the service provider reacts to customers dissatisfaction is key (Durvasula et al., 2000).

The main purpose of this study is to analyze, classify and interpret service failures and recovery strategies encountered in freight forwarding industry, especially the cause of the freight forwarding service failures, course of actions, and the effects of service failures and recoveries on the relationship between the shipper as customer and the freight forwarder as service provider were explored by this research.

The reminder of the study is organized as follows. Section two reviews the literature related to service failures and recovery strategies both in business-to-consumer and business-to-business markets. Section three introduces the research methodology. Section four provides the analysis and results of the study, and the conclusion presents some implications of the findings, limitations, and directions for the future research.

\section{Literature Review on Service Failures and Recovery Strategies}

Service researchers describe service failures as the activities that occur when customer perceptions of initial service delivery behavior fall below the customer's expectations (Zeithaml et.al., 1993; Chou et al., 2009:238). Service failure is considered as a conflict between customers and service providers in terms of fairness of resolution procedures, 
the interpersonal communication and behaviors, and outcomes (Tax, et al., 1998).

Classification of service failure categories by Bitner et al. (1990) is widely adopted and extended within the service failure literature. Service failures have been categorized by them according to employee behaviors when failures occur, relating to the core service, request for customized service and unexpected employee actions. They also emphasized the importance of recovering the service failures such as acknowledging a problem, explaining for the problem, making apologies and compensations. A subsequent study by Bitner et al. (1994) included a typology of problematic customers in their failure classification.

Kelley et al. (1993) determined 15 types of service failure in the retailing industry and classified them under the 3 major groups identified by Bitner et al. (1990). They also analyzed 12 types of recovery strategies in their study. Further Johnston (1995) classified sources of failure in banking industry as attributable to the organization or the customers. Armistead et al. (1995) offered 3 types of service failure: service provider error, customer error, or associated organizational error. Edvardsson (1992) analyzed the sources of service breakdown in airline industry and classified the most common critical incidents in the view of business passengers and service employees. He later explored the causes of customer dissatisfaction in public transportation by critical incident method (CIT). Lewis and McCann (2004) focused on service failure and recovery in the hotel industry and assessed the types and magnitude of service failures encountered and evaluated the service recovery strategies used by hotels. Michel (2001) found that the probability of failure and the degree to which recovery can led to satisfaction is depended on the industry. Hence service failures and recovery strategies need to be need in different industries such as freight forwarding and shipping industry.

Most previous studies concerning service failure and recovery focus on the businessto-customer market, but several researchers extend this approach to the businessto business market. Lockshin and McDougall (1998) studied critical incidents in wine distribution service to evaluate the supplier's recovery strategy. Their findings reveal that service failures in industrial markets are mainly in core or service outcome issues. This is different from service failure in consumer markets which is more related to the process dimension. Chumpitaz and Paparoidamis (2004) suggest that errors and delays during the service exchange can cause customer dissatisfaction in the information technology sector. Durvasula et al. (2000) examine service recovery and satisfaction with ocean shipping industry, exploring that service recovery methods are associated with customer satisfaction levels in business-to-business market. 
Review of the service failure and recovery literature shows that there are two different major types of failures which are outcome failure and process or interactions failure (Grönroos, 1988; Parasuraman et al., 1991; Keaveney, 1995; Smith et al., 1999; Michel, 2001; Johnston and Michel, 2008; Swanson and Hsu, 2009). The occurrence of an outcome failure is worse for the company since it is a core failure and implicates a higher risk of losing the customer when compared to a process failure. The outcome failure motivates the service provider to put more effort into the recovery than process failure (Chou et al., 2009; Bitner et al., 1990; Hoffman et al., 1995; Keaveney, 1995; Mohr and Bitner, 1995; Grönroos, 1988; Parasuraman et al. 1985; Smith et al., 1999). The outcome failure is where the customer does not receive the service paid for, whereas the process failure refers to a disruption whilst receiving the aforementioned service (Smith et al., 1999). Analysis of service failures in the literature founded that the customers tend to be more satisfied with process failure than outcome failures. The buyer in business to business services is mainly concerned with the outcomes or results which means whether promised services received or not by in the outcome-based services such as logistics services.

The service failure literature also considers service failure magnitude (Bolton and Drew, 1992; Bitner et al., 1994; Zeithaml et al.,1996; Bolton, 1998; Smith et al., 1999; Michel, 2001; Zhu et al., 2004) and frequency (McCollough et al., 2000; Michel, 2001) in addition to service failure type (Bitner et al., 1994; Zeithaml et al.,1996; Bolton, 1998; Smith et al., 1999; Craighead et al., 2004; Swanson and Hsu, 2009). Service failure magnitude, severity and criticality all refer to the perception of the customer on the service failure and how the customer evaluates the failure. The service literature has underlined the strong negative impact of failure magnitude of the service failure on customer's future relationship with the service provider (Bell and Zemke, 1987; Berry and Parasuraman, 1991). The more severe the problem is perceived; the greater will be the loss in customer's point of view (Weun et al., 2004). Severe service failures have been identified to decrease the likelihood that a customer will desire to continue the relationship with the service provider (Keaveney, 1995; Craighead et al., 2004).

Service recovery strategy refers to the actions taken in response to a service failure (Grönross, 1988). Recently, the service management literature has focused on diverse aspects of service recovery (Craighead et al., 2004). Service literature indicates three types of recovery methods including symbolic recovery, utilitarian recovery and mixed recovery (Johnston and Michel, 2008; Swanson and Hsu, 2009; Bradley and Sparks, 2012; McDougall, 2000; Zhu et al., 2004). Symbolic recovery stands for the recovery that does not yield an economic outcome for the customer and includes symbolic exchanges such as an apology. It is stated that process service failures require a symbolic service (Smith 
et al., 1999). Utilitarian service recovery is required when there has been an outcome (core) service failure since the outcome service failure creates an economic loss for the customer (Smith et al., 1999). Mixed service recovery represents the use of two or more of the above mentioned service recoveries. These recoveries may be one symbolic and one utilitarian or two symbolic and one utilitarian etc. The main point is that both recovery types are utilized within one recovery effort simultaneously and the choice depends on the type of the service failure at hand (Chou et al., 2009). Service literature also indicates that both service failures and service recoveries strongly influence customer relationships (van Doorn and Verhoef, 2008) and service providers attempt to decrease the negative emotions through effective recovery (Özgen and Duman Kurt, 2012).

Although the relevant literature has widened the theoretical connections of service failure and recovery strategies in different service industries it fails to address, using empirical evidence, the issues of failure types and recovery strategies in logistics and freight forwarding industry in business-to-business market.

Service recovery is important in the logistics industry due to the industry's trend toward proactive approach to service failure (Brinsmead, 2007). It must be noted that both business to consumer and business to business contexts are similar in customer expectations and perceptions related with the failure that in a sense that it's still an individual making the decisions on the customers end whether it is for themselves or for the company they work for (Chou et al., 2009). However, it must be noted that within the business to business services perspective service failures have a higher impact since they usually create major economic consequences (van Doorn and Verhoef, 2008). In addition, the differences between business to consumer and business to business service environments in failure recovery perspective are: business to business failure could have greater chance of damage since it can affect both the company and the customers of the buying company, the involvement of multiple customers on the buyer company's side, the perception of failure and the recovery is greatly affected by the relationship between the buyer company and the supplier company and finally the operational features and legal limits in business to business transactions affect customer satisfaction and thus long term contracts between parties (Flores and Primo, 2008).

The logistics service quality has been examined through reliability, timely responsiveness, accuracy in documentation, accuracy in information, service fulfillment, problem solving ability and empathy dimensions as well (Stewart, 1995; Beamon, 1999; Gunasekaran et al., 2001, Mentzer et al., 2001; Panayides and So, 2005). The strength of the tie between the logistics service provider and its customer has an impact on the economic outcomes of the company. This is due to the service is being provided in a coordinated manner and eventually leading to higher levels of logistics service quality. The service quality 
and exchange processes are directly affected by the information exchange, accuracy, flexibility and solidarity due to the strength of the relationship between the logistics service provider and its customer (Panayides and So, 2005). It is clear that freight forwarders as third party logistics service providers should enhance the perceived quality of shippers in order to achieve higher customer satisfaction rates and ensure an increase in their market share (Qureshi et al., 2007).

Performances of service providers, service failures and recovery strategies in freight forwarding and logistics industry are very crucial. Because shippers outsource their logistics activities and depend on service providers such as freight forwarders, third party logistics companies and carriers to manage a bundle of services. If the freight forwarders fails to perform the complex logistics activities such as booking, documentation, information and communication accurately or fails to deliver the goods on time and safely, the shipper may be affected negatively in terms of lost sales and bureaucratic processes to correct it. Most shippers have encountered mistakes and errors during the course of their logistics service buying experiences. Freight forwarders offering logistics services spend a great deal of time and effort to solve shipper problems. Hence, when a service problem occurs, it is necessary for freight forwarders to solve and handle the claims through the effective recovery strategies.

\section{Research Methodology and Model}

Business and marketing research have applied the critical incident technique (CIT) in a wide variety of circumstances (Kelley et al., 1993:430) and founded that both in business to consumer and business to business services CIT was a useful method in discovering service problems and recovery strategies (Bitner et al., 1990; Bitner et al., 1994; Hoffman et al., 1995; Lockshin and McDougall, 1998). This was taken as an opportunity to examine the service failures and recovery strategies in freight forwarding service as a business to business service. Therefore, this study employed the CIT in analyzing service failures and recovery methods in freight forwarding industry.

$\mathrm{CIT}$ is a set of procedures enabling to collect and classify certain observations on human behaviors so as to help find solutions to various problems encountered in certain actions (Bitner et. al., 1990). It was developed and originated in the USA during 1940's by Flanagan (1954) by pointing out how it had been used in recruiting candidate pilots for the American Air force. In service-related research, many of those on service quality and service failures seem to have used CIT. The findings of various researches have encouraged the use of CIT for specific purposes involving the measurement of quality and tracking the service failures and recovery strategies in a great deal of service types in many countries (Stauss 
and Weinlich, 1997; Edvardsson, 1990, 1992, 1998; Lundberg, 2011).

A means of measuring service quality and discovering service failures, $\mathrm{CIT}$ is thought to define service encounters, provide detailed information about service failures, and help investigate and better understand to situations where quality weaknesses exist. Critical incidents may refer to "specific unfavorable incidents" and are special, problematic, unpleasant to the customers who has not got what they expected (Edvardsson, 1998). In this study service failures encountered in forwarding services were referred as critical incidents. Shippers as customers of freight forwarders express their own dissatisfaction concerning a particular freight forwarding service which means that CIT is based on perceptions. CIT is based on such expressions, and experiences taken as data, and their classification. This means that CIT is not only concerned with collecting information about the most problematic aspects of services, but it is also concerned with developing a system of interpreting and classifying this information. In other words, through this technique, a preliminary idea is gained and going further, the content is acquired, which would help interpretation, and eventually more detailed acquisition is reached. Emphasizing the importance of interpretation means that the researcher has adopted a kind of phenomenal approach. The phenomenal approach implies that the actor acquires the social phenomena through his/her own perspectives (Edvardsson, 1992). Many people enjoy talking about their experiences again and again about the services they are provided with. CIT simply puts this process into a formal dimension through which the experiences are recorded, analyzed, and eventually certain data are collected and made use of on the way to improve service quality.

While being used in classifying the customer satisfying and dissatisfying incidents, CIT are also used in collecting and classifying unfavorable critical incidents only such as service failures. Edvardsson $(1992 ; 1998)$ studied only on the unfavorable critical incidents (service failures) encountered in airway and public transport services. Likewise, Hoffman et al., (1995) collected and classified the service failures and recovery strategies encountered in restaurant services. Lockshin and McDougall (1998) analyzed the problems bringing about customer dissatisfaction by CIT in wine distribution services:

The CIT methodology involves 6 steps (Flanagan, 1954; Keller, 1993; Hoffman, et al., 1995);

1. determine the general aims of the activity (determined in the introduction section)

2. formulate plans and specifications for the collections of critical incidents

3. collect the data on critical incidents

4. analyze the data in order to identify patterns 
5. classify the incidents in the various categories

6. interpret the data and draw the conclusions

In this research, the critical incident is defined only as the specific unfavorable critical incident, service failure or problem that has, in the last one year, brought about customer dissatisfaction within the interaction between customers and freight forwarding service providing employees. While detecting the service failures, the experiences of both the shippers as customers and freight forwarders were made use of. They were asked to remember an incident in detail and respond to the relevant questions accordingly. Both respondents were asked to remember a critical incident and explain it. Later, they were asked about the reasons underlying the occurrence of this failure and they were asked to rate the magnitude and frequency of the failure from one to ten. Respondents were also asked about the recovery attempt and how they rated the effectiveness of the recovery again on a ten point scale. Finally, the questionnaire concluded with getting respondents opinion on how the relationship was influenced by the failure.

This research wherein freight forwarding service failures are detected, the research model used by Edvardsson $(1992 ; 1998)$ has been adopted. This model puts forward a standardized form for researching the service failures and recoveries. In this model, the questions directed to the participant simply involve

the cause of the critical incident, the course of actions towards the critical incident, and the resultant effects of this reaction on the interaction between the customer and the service providing company.

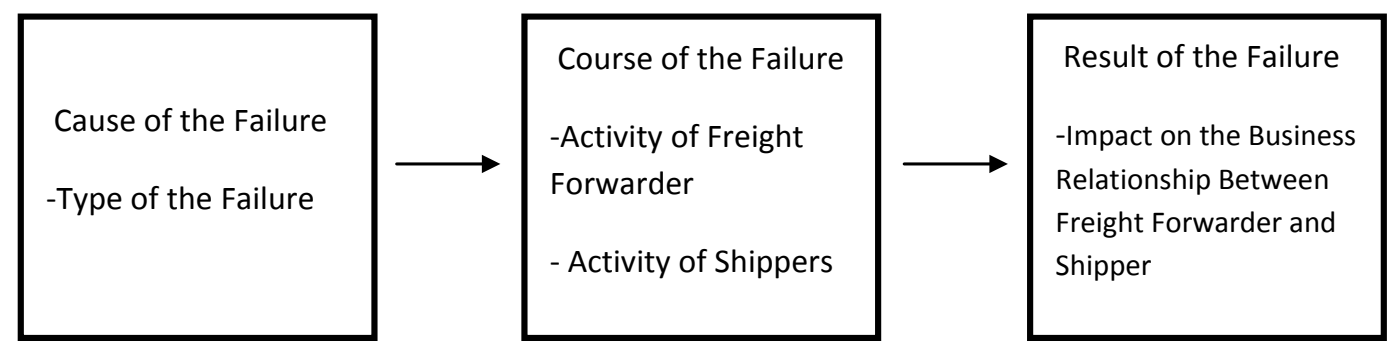

Figure 1:

Research Model

The cause, course and result model of Edvardsson (1992) was utilized in this study. The cause of the failure indicates the type of the failure, the course phase focuses on the activity of freight forwarders and shippers, and finally, the results underline the impact of the failure on the business relationship between parties. 


\section{a. Sampling and Data Collection}

In CIT the data constitute the stories of the respondents or participants. The participants are the customers and the service employees, only actors who can release their experiences concerning the service failures and problems encountered in the service process. A number of different techniques for data collection have been employed in CIT studies such as (student) interviewers, author interviewers and other research instruments such as self-expressive methods, mail or internet based surveys, group meetings (Gremler, 2004; Öztürk, 2000). In this study, the in depth interview method was used in data collection by using structured interview form. Each interview took approximately 30 minutes. The shippers as customers of freight forwarders were individually asked to recall and describe service failures they encountered highlighting the cause, course and result of each of the incidents. They were then required to give further information about the unclear parts of each story. The experiences imply that this method would work well particularly in case of unclear critical incidents as it would allow to collect detailed information in order to secure the validity of the research, the concept of "critical incidents" was clarified.

Although there exist no strict rules enforced in collecting critical incident techniques about the number of incidents to be involved, it is suggested that the more the better in favor of reaching reliable analyses. Precisely stating, while around 50 incidents would be acceptable in terms of gaining reliable classifications, collecting around 100 incidents would enable much reliable categories (Gremler, 2004).

Reaching the right number, however, would still vary depending upon the feature of the analysis. For instance, researchers on the organizational service markets would require fewer incidents than would those on customer service markets.

Judgmental sampling was used in the selection of the sample for the study. The critical incidents related to freight forwarding service failures and recovery strategies were collected from the shippers included in the list of the members to Aegean Region Union of Exporters and from the freight forwarders included in the registry records of the Association of International Forwarding and Logistics Service Providers in 2011. As a result, the total number of the critical incidents related to service failures and recoveries in freight forwarding collected is 100; 50 incidents from shippers and 50 incidents from freight forwarders. Both the shippers and freight forwarders were each asked to give information about only one critical incident including the service failures and recovery strategies they encountered. Shippers and freight forwarders were asked to recall and recount in detail, in his/her own words, a service failure or error he had encountered in freight forwarding services. 


\section{b. Reliability}

$\mathrm{CIT}$ is considered to be in the same group with inductive classifying procedures (Öztürk, 2000). In this technique, groups or categories are formed based on the analysis of the cases or stories explained by the respondents themselves rather than statistical aspects. Based on the contents of the cases expressed, the similar incidents were categorized in certain groups through a step-by-step classifying process. The researcher in CIT is expected to reach truth, considering every small part of the cases expressed. Hence, in this research, the key words and phrases of each case were used to form certain common themes. The analysis of the data collected was carried out through two steps: In the first step, a series of categories which would include critical incidents were developed and defined. In the second step, in order to find relative frequency of the incidents in each category, the critical incidents collected were classified in these categories.

In data analysis, first considering the common points of the service failures expressed by the shippers and freight forwarders were categorized and classified in these categories. While classifying the incidents, they were read again and again to find out the common points. Following this classification, the groups were defined in details and in order to reach reliable grouping, the incidents were again categorized. Eventually, well-clarified category definitions were gained.

The critical incidents in this study were classified by two independently researchers. Where differences occurred, they were resolved through discussion. At least $80 \%$ agreement on each category was considered to be satisfactory for the reliability of the classifying system. After the researchers have read many service failure incidents, they saw the common points more clearly, and then the exact structure of the common points was explored, which would form the base for naming the incidents in each category. The classification task was repeated and revised again and again until making sure that all the incidents in one category are more alike with one another than they were with the others in another category.

\section{Analysis and Results}

The findings of the research are two-fold: Analyzing the freight forwarding service failures from the shipper perspectives and analyzing the service failures from the viewpoints of the freight forwarders' service employees. The findings were handled in compliance with the research model mentioned in the research methodology section. In the following section first sippers' experiences and perceptions were analyzed, then freight forwarder employees' experiences related to service failures and recovery strategies were analyzed. 


\section{a. Results-Shippers}

The analysis and results of sorting and classification process for the data collected from shippers are reported below. First the failure classification scheme based on the cause of the failure is given, followed by the presentation of the types of actions taken by both the shippers and freight forwarders. Third, the effects of the service failures and recovery actions on the relationship between the shippers and freight forwarders are presented.

\section{i) Cause}

The classification of failures in freight forwarding services according to the shippers' experiences and perceptions is given in Table 1 . The failure sorting and classification resulted in 6 unique main types of failures.

The most prevalent and common type of service failures in the view of shippers researched are related to documentation (28\%) and, information and communication (26\%). The sub-categories of documentation failures ranked on the following scale: bill of lading error (5), invoicing error (5), and errors in customs declarations (4). When it comes to information and communication failures, service failures are often the result of errors in informing shippers (9). Lack of employees' professional knowledge ranked second in this category of service failure. Shippers generally use freight forwarders for their advice, expertise and knowledge related to the international trade and logistics. Failure to provide professional knowledge by the forwarder employee may cause service failures. 
Table 1:

Failures in Freight Forwarding Services: Shippers' Point of View

\begin{tabular}{|c|c|c|c|}
\hline Failure Type & $\begin{array}{l}\text { Count } \\
\text { (N) }\end{array}$ & $\begin{array}{l}\text { Frequency } \\
\text { (\%) }\end{array}$ & $\begin{array}{l}\text { Magnitude of } \\
\text { Failure* }\end{array}$ \\
\hline \multicolumn{4}{|l|}{ Group 1: Documentation failures } \\
\hline 1B. Bill of lading error & 5 & 10 & 6.6 \\
\hline 1C. Invoicing error & 5 & 10 & 7.8 \\
\hline 1D. Customs declaration error & 4 & 8 & 8 \\
\hline Group 1 Total & 14 & 28 & 7.46 \\
\hline \multicolumn{4}{|l|}{ Group 2: Information and communication failures } \\
\hline 2A. Customer information errors & 9 & 18 & 8.4 \\
\hline 2B. Lack of employees" professional knowledge & 3 & 6 & 9 \\
\hline 2C. Communication failures & 1 & 2 & 9 \\
\hline Group 2 Total & 13 & 26 & 8.8 \\
\hline \multicolumn{4}{|l|}{ Group 3: Operational failures } \\
\hline 3A. Cargo handling error & 4 & 8 & 9.6 \\
\hline 3B. Unreliability of transit time & 2 & 4 & 8.5 \\
\hline 3C. Pick up error & 1 & 2 & 8 \\
\hline Group 3 Total & 7 & 14 & 8.7 \\
\hline \multicolumn{4}{|l|}{ Group 4: Equipment failures } \\
\hline 4A. Damaged and unclean containers & 4 & 8 & 9.7 \\
\hline 4B. Unavailable equipment & 3 & 6 & 5 \\
\hline Group 4 Total & 7 & 14 & 7.35 \\
\hline \multicolumn{4}{|l|}{ Group 5: Booking failures } \\
\hline 5A. Booking error & 6 & 12 & 8.3 \\
\hline Group 5 Total & 6 & 12 & 8.3 \\
\hline \multicolumn{4}{|l|}{ Group 6: Delivery failures } \\
\hline 6A. Late delivery & 2 & 4 & 8,5 \\
\hline 6B. Delivery without bill of lading & 1 & 2 & 10 \\
\hline Group 6 Total & 3 & 6 & 9.25 \\
\hline Total & 50 & 100 & \\
\hline
\end{tabular}

*1: Minor 10: Major

The study shows that 14 service failures result from operations including errors in cargo handling, unreliability of transit time promised and pick up error. The number of equipment related service failures was 7 in the study. These are primarily a matter of damaged and unclean containers and unavailable equipment for the shippers. The failures encountered 
with low frequency are the ones related with the delivery (6\%). The sub group of delivery failures is late delivery (2) and delivery without bill of lading (1).

In terms of failure magnitude, delivery related failures perceived highest in the rate (9.25), which is followed by information and communication failures and operational failures. From the perspective of shippers, documentation failures were rated the least important ones compared to magnitudes of other service failures (7.46).

\section{ii) Course}

As regards the course of actions, the commitment of both freight forwarders and the shippers to "set the work" on service failures and their actual activities were focused. Shipper behaviours against the service failures caused by freight forwarders are displayed in Table 2. As could be seen in this table shipper behaviours were categorized as active and passive respectively. Table 2 reveals that $84 \%$ of shippers were active after they encountered forwading service failures. It is clear that the highest percentage in the shipper behaviors is with verbal warning $(22 \%)$. This is followed by the written complaints with $20 \%$, and objections to paying the expenditures with $16 \%$. Only in a few cases, 8 service failures, did the shipper remain passive to service failures.

Table 2:

The Actions of the Shippers

\begin{tabular}{|l|l|l|l|}
\hline \multirow{5}{*}{} & Actions of shippers & $\begin{array}{l}\text { Number } \\
\text { (N) }\end{array}$ & $\begin{array}{l}\text { Percentage } \\
\text { (\%) }\end{array}$ \\
\hline \multirow{5}{*}{ Active } & Verbal warnings & 11 & 22 \\
\cline { 2 - 5 } & Written complaints & 10 & 20 \\
\cline { 2 - 5 } & Objection to paying expenditures & 8 & 16 \\
\cline { 2 - 5 } & Informing the consignee & 5 & 10 \\
\cline { 2 - 5 } & Informing the freight forwarder & 4 & 8 \\
\cline { 2 - 5 } & Others & 4 & 8 \\
\hline \multirow{4}{*}{ Passive } & Notal response from the shipper & $\mathbf{4 2}$ & $\mathbf{8 4}$ \\
\cline { 2 - 5 } & Total & 8 & 16 \\
\hline & Overall Total & $\mathbf{8}$ & $\mathbf{1 6}$ \\
\hline
\end{tabular}

The actions taken by freight forwarders and service recovery strategies employed by them are also classified as active and passive. Table 3 shows that the freight forwarder staffs were active in 34 service failures (68\%) and passive in 16 service failures (32\%) with 
no actions.

The shippers said that the freight forwarders apologized in 16 critical incidents, met all loses/damages in 5 service failures and paid back the certain amount of costs incurred by shippers in 5 service failure incidents.

From the viewpoints of the shippers; the most effective means of service recovery by freight forwarders seems to be meeting all the losses/damages of shippers, which is followed by the method of paying back to a certain extent. The least effective service recovery method is seen by the shippers as apologizing.

Table 3:

The Actions of the Freight Forwarders

\begin{tabular}{|l|l|l|l|l|}
\hline \multirow{7}{*}{} & Actions of freight forwarder & Number & Percentage \\
$(\mathbf{N})$ & $\begin{array}{l}\text { Recovery } \\
\text { rating }\end{array}$ & \\
\hline \multirow{5}{*}{ Active } & Apologizing & 16 & 32 & 4.8 \\
\cline { 2 - 6 } & Meeting all losses / damages & 5 & 10 & 7 \\
\cline { 2 - 6 } & Paying back certain amount & 5 & 10 & 6.4 \\
\cline { 2 - 6 } & Discounting freight and expenditures & 4 & 8 & 6 \\
\cline { 2 - 6 } & Others & 4 & 8 & 5.5 \\
\hline \multirow{2}{*}{ Passive } & Total & 34 & 68 & 5.9 \\
\hline & Offering no help and solutions & 16 & 32 & \\
\hline & Total & 16 & 32 & \\
\hline
\end{tabular}

1= Very poor 10=Very good

\section{iii) Results}

Table 4 shows that in $28 \%$ of the cases the service failures studied resulted in unchanged shipper relations. In $66 \%$ of the cases the service failures resulted in a weakened or broken and $6 \%$ of the cases in a strengthened relationship as perceived by the shippers. Thus the freight forwarders were in many cases not able to deal with the service failures in a satisfactory manner from the shipper's viewpoint. 
Table 4:

The Effect of the Service Failures on the Shippers' Relations with the Freight Forwarders

\begin{tabular}{|l|l|l|}
\hline $\begin{array}{l}\text { The effect of service failures on the shippers' relations with the } \\
\text { forwarder }\end{array}$ & $\begin{array}{l}\text { Number } \\
\text { (N) }\end{array}$ & $\begin{array}{l}\text { Percentage } \\
\text { (\%) }\end{array}$ \\
\hline Relations broken & 15 & 30 \\
\hline Relations weakened & 18 & 36 \\
\hline Relations unchanged & 14 & 28 \\
\hline Relations strengthened & 3 & 6 \\
\hline Total & $\mathbf{5 0}$ & $\mathbf{1 0 0}$ \\
\hline
\end{tabular}

\section{b. Results - Freight Forwarders' Employee i) Cause}

Staffs of the freight forwarders were also asked to describe, on the basis of their experience and understanding, what the shipper experiences as negative critical incidents in relation to freight forwarder services.

Table 5 reveals that the number of main group of service failures from the freight forwarder employees' point of view is 7. These failures are ranked on the bases of descending scales: operational failures (12), documentation failures (11), booking failures (9\%), information and communication failures (6), problem shippers (5), delivery failures (4) and equipment failures (3).

The first 3 main groups of service failure account $64 \%$ of the freight forwarding service failures. The staff of freight forwarders surveyed believed that $24 \%$ of service failures arose in connection with the forwarding operations. The degree of prevalence in the subgroups of the operational failures shows that the most prevalent one is related with failure to find place on ships (\%12), which is followed with the same level of prevalence by cargo handling errors and pick up errors (6\%). 11 service failures in connection with the documentation were sub-categorized as bill of lading error (6), invoicing error (4), and error in customs declaration (1). $10 \%$ of the service failures (5) are caused by the shippers due to the incomplete or wrong information given to freight forwarders. This shows that in addition to the staff of the freight forwarders in some cases shippers himself/herself might cause the failures in freight forwarding services. When it comes to the delivery failures, service failures are often delay in delivery or damaged delivery. 
Table 5:

Failures in Freight Forwarding Services: The Freight Forwarder Employee Viewpoints

\begin{tabular}{|c|c|c|c|}
\hline Failure Type & $\begin{array}{l}\text { Count } \\
\text { (N) }\end{array}$ & $\begin{array}{l}\text { Frequency } \\
(\%)\end{array}$ & $\begin{array}{l}\text { Magnitude of } \\
\text { Failure* }\end{array}$ \\
\hline \multicolumn{4}{|l|}{ Group 1: Operational failures } \\
\hline 1A. Unavailable place on the ships & 6 & 12 & 7.6 \\
\hline 1B. Cargo handling error & 3 & 6 & 9 \\
\hline 1C. Pick up error & 3 & 6 & 8.6 \\
\hline Group 1 Total & 12 & 24 & 8.4 \\
\hline \multicolumn{4}{|l|}{ Group 2: Documentation failures } \\
\hline 2A. Bill of lading error & 6 & 12 & 8 \\
\hline 2B. Invoicing error & 4 & 8 & 7.7 \\
\hline 2C. Errors in customs declarations & 1 & 2 & 9 \\
\hline Group 2 Total & 11 & 22 & 8.2 \\
\hline \multicolumn{4}{|l|}{ Group 3: Booking failures } \\
\hline 3A. Booking errors & 9 & 18 & 8.3 \\
\hline Group 3 Total & 9 & 18 & 8.3 \\
\hline \multicolumn{4}{|l|}{ Group 4: Information and communication failures } \\
\hline 4A. Customer information failure & 2 & 4 & 8 \\
\hline 4B. Wrong quotation & 2 & 4 & 8.5 \\
\hline 4C. Communication failure & 1 & 2 & 9 \\
\hline 4C. Lack of employees' professional knowledge & 1 & 2 & 10 \\
\hline Group 4 Total & 6 & 12 & 8.87 \\
\hline \multicolumn{4}{|l|}{ Group 5: Problem shippers } \\
\hline 5A. Incomplete/wrong information from shippers & 4 & 8 & 7.5 \\
\hline 5B. Reservation change by shipper & 1 & 2 & 10 \\
\hline Group 5 Total & 5 & 10 & 8.75 \\
\hline \multicolumn{4}{|l|}{ Group 6: Delivery failures } \\
\hline 6A. Delay in delivery & 3 & 6 & 8 \\
\hline 6B. Damaged delivery & 1 & 2 & 10 \\
\hline Group 6 Total & 4 & 8 & 9 \\
\hline \multicolumn{4}{|l|}{ Group 7: Equipment failures } \\
\hline 7A. Damaged and unclean containers & 2 & 4 & 8.5 \\
\hline 7B. Equipment shortages & 1 & 2 & 10 \\
\hline Group 7 Total & 3 & 6 & 9.25 \\
\hline Grand Total & 50 & 100 & \\
\hline
\end{tabular}

*1: Minor 10: Major 
As for the magnitude of service failures, the table reveals that the most important failures are related with the equipment, which is followed by delivery failures. These failures are considered as core service failures both by the shippers and forwarder staff affecting the output of the service, hence they are assumed as the most serious mistake that cause customer dissatisfaction.

\section{ii) Course}

Table 6 reveals that agreat percentage of the shippers actions against the freight forwarding service failures involves active behaviours (88\%), and the highest rate in this category is related with aggressive behaviours (24\%), which is followed by demand a change in the carrier used by the freight forwarder (18\%).

Table 7 reveals that from the viewpoint of freight forwarders, the most frequently used service recovery method is compensating all the losses and damages (18\%), which is respectively followed by explaining the situation (16\%), demanding a change in the suppliers and carriers (14\%), and apologizing (14\%).

Table 6:

The Actions of the Shippers: The Freight Forwarder Employee's Viewpoint

\begin{tabular}{|l|l|l|l|}
\hline \multirow{4}{*}{} & Actions of shippers & $\begin{array}{l}\text { Number } \\
\text { (N) }\end{array}$ & $\begin{array}{l}\text { Percentage } \\
\text { (\%) }\end{array}$ \\
\hline \multirow{5}{*}{ Active } & Displaying aggressive behavior & 12 & 24 \\
\cline { 2 - 4 } & Demanding a change in the carrier used by forwarder & 9 & 18 \\
\cline { 2 - 5 } & Exhibiting sympathy and understanding & 5 & 10 \\
\cline { 2 - 5 } & Reflecting the expenditures incurred to the forwarder & 4 & 8 \\
\cline { 2 - 5 } & Informing the forwarder so as the speed up the recovery & 4 & 8 \\
\cline { 2 - 5 } & Informing the consignee & 4 & 8 \\
\cline { 2 - 5 } & Warning the forwarder written & 2 & 4 \\
\cline { 2 - 5 } & Verbally complaining & 2 & 4 \\
\cline { 2 - 5 } & Sharing the expenditures/costs & 1 & 2 \\
\cline { 2 - 5 } & Using legal means for the recovery of failure & 1 & 2 \\
\cline { 2 - 5 } & Total & 44 & 88 \\
\hline \multirow{4}{*}{ Passive } & Displaying no actions/no response & 6 & 12 \\
\cline { 2 - 5 } & Total & 6 & $\mathbf{1 2}$ \\
\hline & Overall Total & $\mathbf{5 0}$ & 100 \\
\hline
\end{tabular}


As for the effectiveness of the recovery strategy adopted on service failures, the table reveals that the most effective means of recovery is providing new containers, which is followed by correcting bill of lading and invoices, booking, and meeting all losses and damages.

Table 7:

The Actions of the Freight Forwarders: The Freight Forwarder Employee Viewpoints

\begin{tabular}{|c|c|c|c|c|}
\hline & Actions of Freight Forwarder & $\begin{array}{l}\text { Number } \\
\text { (N) }\end{array}$ & $\begin{array}{l}\text { Percentage } \\
\text { (\%) }\end{array}$ & Recovery rating* \\
\hline \multirow{10}{*}{ Active } & Meeting all losses / damages & 9 & 18 & 7.56 \\
\hline & Giving convincing explanations & 8 & 16 & 5.87 \\
\hline & $\begin{array}{l}\text { Changing service suppliers and car- } \\
\text { riers }\end{array}$ & 7 & 14 & 6.57 \\
\hline & Apologizing & 7 & 14 & 6.57 \\
\hline & Correcting bill of lading and invoices & 5 & 10 & 8 \\
\hline & Correcting booking & 4 & 8 & 8 \\
\hline & Partial returning & 4 & 8 & 6.5 \\
\hline & Providing new containers & 2 & 4 & 8.5 \\
\hline & Other actions & 1 & 2 & 6 \\
\hline & Total & 47 & 94 & 6.56 \\
\hline \multirow{3}{*}{ Passive } & Being indifferent/No Actions & 3 & 6 & \\
\hline & Total & 3 & 6 & \\
\hline & Overall Total & 50 & 100 & \\
\hline
\end{tabular}

$1=$ Very poor $10=$ Very good

\section{iii) Results}

Table 8 reveals that in most of the critical incidents involved in the research, the service failures did not cause any noticeable changes in the relationship between the shippers and the freight forwarders (38\%). In about one fourth of the cases (24\%), the service failures seem to have weakened the relationships, and surprisingly in one fifth of the cases involved, service failures and recovery methods strengthened the relations between the two parties. 
Table 8:

The Effects of the Critical Incidents on the Shippers' Relations with the Freight Forwarders: The Freight Forwarder Employee Viewpoints

\begin{tabular}{|l|l|l|}
\hline Resultant Effects & $\begin{array}{l}\text { Number } \\
\text { (N) }\end{array}$ & $\begin{array}{l}\text { Percentage } \\
\text { (\%) }\end{array}$ \\
\hline Relations Broken & 9 & 18 \\
\hline Relations Weakened & 12 & 24 \\
\hline Relations Not Changed & 19 & 38 \\
\hline Relations Strengthened & 10 & 20 \\
\hline Total & $\mathbf{5 0}$ & $\mathbf{1 0 0}$ \\
\hline
\end{tabular}

\section{Conclusions}

This study aimed to analyze the service failures and recovery strategies encountered in freight forwarding industry. The overall analysis involved defining and categorizing the prevalant service failures, the likely causes of this unfavorable ones and recovery strategies for such failures in freight forwarding services. The analysis also involved comparing and contrasting the perceptions of shippers and those of freight forwarders. In order to realize the aims of the research CIT was used. The reseach model used in this study involved three basic components; causes of the service failure, actions taken to recover the failure, and eventual effects of the service failure and recovery on the business relations between the shipper and freight forwarder. As a result, at total of 100 service failure incidents collected from shippers and freight forwarders were categorized by means of CIT.

The findings of the study proves that CIT is a proper and useful technique in not only collecting detailed information about service failures in busines-to-business service failures but also developing a system of classfying and interpreting such critical incidents. A means of measuring perceived service quality and exploring the service failures and effectiveness of the recovery strategies, CIT is thought to define and classify service encounters and delivery processes, provide detailed information about the service failures.

The results of the study reveal that the most prevalant service failures in freight forwarding services, based on the views of the shippers are related with documentation, information and communication, operations including cargo handling and picking up container. The further specific analysis indicate that documentation failure comprises bill of lading error, invoicing error and errors in customs declarations; information and communication related failures include errors in informing customers, lack of professional knowledge 
of service employees and errors in communication with shippers. Operational failures mainly cover cargo handling errors and unreliability of transit time. Equipment related failures involve damaged and unclean containers and unavailable equipment. From the viewpoints of shippers, delivery related failures are encountered with the lowest frequency but perceived highest magnitude. The higher magnitude of delivery related service failure is strongly related with the size of loss for the customers (Smith, 1999) and thus it is expected that these types of failures require utilitarian service recovery from the freight forwarders since they are related with the outcome dimension of the logistics and forwarding service. As mentioned earlier in the review of service failure and recovery strategy outcome failure is worse for the service provider company and requires more effort into recovery than the process failures (Chou et al., 2009; Smith, 1999).

The actions taken by shippers against service failures were in two basic categories such as active and passive. The highest percentage in the shipper actions is with verbal warning followed by written complaints, and objections to paying the expenditures incurred to the service failure encountered. The freight forwarder staffs were active and employed recovery methods almost in $2 / 3$ of the service failures and passive in $1 / 3$ of the incidents with no actions. The freight forwarders used apology with $32 \%$ as a service recovery in the service failures encountered and met all loses/damages in $10 \%$ of service failures and paid back the certain amount of costs incurred by shippers in 5 critical incidents. From the viewpoints of the shippers; the most effective means of service recovery by freight forwarders seems to be meeting all the losses/damages of shippers, which is followed by the method of paying back to a certain extent. The least effective service recovery method is seen by the shippers as apologizing. This finding supports the study of Lockshin and McDougall (1998) in such a way that customers in business to business services are more concerned with the recovery of the core service and prefer utilitarian strategy.

As for the viewpoints and experience of freight forwarders employees, service failures are categorized into 7 main categories. The most prevalent one is operational failures, documentation failures and booking failures and the least prevalent one is related with equipment related failures. Perspective of freight forwarders' employee added new type of service failure category and this category is labelled as problem shippers. These types of failures occur due to the incomplete or wrong information from the shippers. Similar failure category was also included in the study of Bitner et al., 1994's study in air transportation. Since customers are involved in the production of the customers may be the cause of the failure sometimes. Missing or wrong information sent from shipper to freight forwarder may cause faulty service operation, documentation or delivery by the freight forwarder employees. The magnitude of equipment related failures and delivery failures were considered as major failures compared to other failures by the freight 
forwarder employees. Since these dimensions of forwarding service are related to the service outcome the failures in these dimensions are considered as important failures.

The recovery methods mainly used by freight forwarders are respectively meeting all the loss and damage and giving convincing explanations about the failures, changing the carrier used by freight forwarder. The most effective means of recovery seems to be providing new containers and meeting all losses and damages. This means that shippers are mainly interested in the outcome dimension of the service rather than the failures in the service processes. Hence utilitarian recoveries are considered to be more important than symbolic recoveries in freight forwarding services.

As for as the effects of freight forwarding service failures and recoveries on the relationship between the shippers and freight forwarders are concerned, the critical incidents defined do not cause any noticeable changes in the relationship. The analysis reveals that about in one fourth of the incidents, the relationships seem to have strengthened. These findings support in business to business service there are limited number of service suppliers compared to business to consumer services and the relationship between the service suppliers and customers are very close, hence if the service failure encountered is recovered effectively by the service provider it is possible that the relationship between the customer and the service provider may be strengthened.

Comparing the perceptions of the service providers and the shippers reveals that the most often encountered service failures are errors in documentation and failures in information and communication from the sippers' viewpoint operational failures and documentation failures from the freight forwarders viewpoint. The least often encountered service failures are related with the delivery in both perceptions.

The study concluded that majority of the freight forwarding service failures are caused by freight forwarder. Hence, freight forwarders should train their personnel in order to avoid service failures and employ effective service recovery strategy. Claims handling or complaint handling departments existing in the shipping lines is suggested to be established in the freight forwarders to analyze service failures and employ effective recovery strategies.

Moreover, utilizing advanced information and communication technologies that enable seamless information exchange between parties with minimum personnel error will help freight forwarders avoid failures regarding information, communication, documentation and booking.

Hence it has been observed that some of the leading freight forwarders have been heavily investing in these technologies in order to prevent such failures. 
Considering the complexities and degree of risk in in the freight forwarding services liability insurance coverage against the risks and service failures can be an effective way for freight forwarders.

As a logistics service freight forwarding services is a matter of controlling details in the whole logistics service process and delivery, the quality improvement means improving all the parts of the logistics service chain and seeing whole supply chain. Most of the literature in the service failure and recovery focus on the detail, "company level" but actually they shoud be studying service failures and recovery in the supply chain as a whole. From the final customers' perspective it is necessary that whole supply chain functions properly. It will be very useful to take service failures and recovery strategies at different satages in the supply chain and logistics service process and study both shippers and the freight forwarder staff involved about the same service failures. The more reseachers know about service failures in the whole logistics service chain, the better the basis for further and continuous recovery strategy development.

Future studies on service failures in freight forwarding industry should consider customer complaint documents in analyzing the service failures. Also the sample size could be widened and compared with other countries due to differences in terms of logistics sytems, regulations, infrastructures and cultures. In addition, utilizing the same techniques in other business to business services is advised in order to generalize the findings.

This study is limited by its exploratory design and qualitative methods used. Future studies could use other methods such as focus group study, experimental design and survey methods to improve empirical generalizability. Future studies could adopt a more inclusive approach and incorporate insights from other supply chain and logistics chain members related to service encounters, failures and recovery strategies.

\section{REFERENCES}

Armistead, Colin G., Graham Clark and Paule Stanley (1995) "Managing Service Recovery", Cranfield Information Management, Cranfield.

Beamon, Benita M. (1999) "Designing the Green Supply Chain", Logistics Information Management, 12(4), p.332-342.

Bell, Chip R. and Ron E. Zemke (1987) "Service Breakdown: the Road to Recovery", Management Review, 76(10), p.32.

Berry, Leonard L. and Anantharanthan Parasuraman (2004) Marketing Services: Competing through quality, Simon and Schuster. 
Bienstock, Carol C., John T. Mentzer and Monroe Murphy Bird (1996) "Measuring Physical Distribution Service Quality", Journal of the Academy of Marketing Science, 25(1), p.31-44.

Bitner, Mary Jo, Bernard H. Booms and Lois A. Mohr (1994) "Critical Service Encounters: The Employee's Viewpoint", The Journal of Marketing, p.95-106.

Bitner, Mary Jo, Bernard H. Booms and Mary Stanfield Tetreault (1990) "The Service Encounter: Diagnosing Favorable and Unfavorable Incidents", The Journal of Marketing, p.71-84.

Bolton, Ruth N. (1998) “A Dynamic Model of the Duration of the Customer's Relationship with a Continuous Service Provider: The Role of Satisfaction", Marketing Science, 17(1), p.45-65.

Bolton, Ruth N. and James H. Drew (1992) "Mitigating the Effect of Service Encounters", Marketing Letters, 3(1) p.57-70.

Bradley, Graham and Beverley Sparks (2012) "Explanations: If, When, and How They Aid Service Recovery", Journal of Services Marketing, 26(1), p.41-51.

Chou, Christine, Ya-Hui Hsu and Yeong-Jia Goo (2009) "Service Failures and Recovery Strategies from the Service Provider Perspective", Asia Pacific Management Review, 14(2), p.237-249.

Chumpitaz, Ruben and Nicholas G. Paparoidamis (2004) "Service Quality and Marketing Performance in Business-to-Business Markets: Exploring the Mediating Role of Client Satisfaction", Managing Service Quality: An International Journal, 14(2/3), p.235-248.

Craighead, Christopher W., Kirk R. Karwan and Janis L. Miller (2004) "The Effects of Severity of Failure and Customer Loyalty on Service Recovery Strategies", Production and Operations Management, 13(4), p.307-321.

Deveci, Ali (2002) Konteyner Taşımacılığı Gemi Acenteliği Hizmet Hatalarını Ölçmeye Yönelik Bir Araştırma: İmir Limanındaki Gemi Acentelerine Yönelik Uygulama, Unpublished PhD Thesis, Istanbul: Istanbul University Maritime Sciences and Management Institute.

Durvasula, Srinivas, Steven Lysonski and Subhash C. Mehta (2000) "Business-to-Business Marketing Service Recovery and Customer Satisfaction Issues with Ocean Shipping Lines", European Journal of Marketing, 34(3/4), p.433-452.

Edvardsson, Bo (1988) “The Service Encounter: Service Quality in Customer Relationship: 
A Study of Critical Incident in Mechanical Engineering Companies", The Service Industries Journal, 8(4), p.427-445.

Edvardsson, Bo (1992) "Service breakdowns: A Study of Critical Incidents in an Airline", International Journal of Service Management, 3(4), p.17-29.

Edvardsson, Bo (1998) "Causes of Customer Dissatisfaction-Studies of Public Transport by the Critical Incident Method", Managing Service Quality, 8(3), p.189-197.

Flanagan, John. (1954) "The Critical Incident Technique", Psychological Bulletin, 51, p.327-358.

Flores, Luis Antonio Figueira Sanches and Marcos André Mendes Primo (2008) "Failure Recovery Management in Performance of Logistics Services in a B2B Context: A Case Study Using the 3PL Perspective", Journal of Operations and Supply Chain Management, 1(1), p.29-40.

Gremler, Dwayne D. (2004) “The Critical Incident Technique in Service Research”, Journal of Service Research, 7(1), p.65-89.

Gronroos, Christian (1988) "Service Quality: The Six Criteria of Good Perceived Service Quality", Review of Business, 9(3), p.10-13.

Gunasekaran, Angappa, Chaitali Patel and Ercan Tirtiroglu (2001) “Performance Measures and Metrics in a Supply Chain Environment", International Journal of Operations and Production Management, 2(1-2), p.71-87.

Hess, Ronald L., Shankar Ganesan and Noreen M. Klein (2003) "Service Failure and Recovery: The Impact of Relationship Factors on Customer Satisfaction", Journal of Academy of Marketing Science, 31(2), p.127-145.

Hoffman, K. Douglas, Scott W. Kelley and Holly M. Rotalsky (1995) “Tracking Service Failure and Employee Recovery Efforts", Journal of Services Marketing, 9(1), p.49-61.

Nyquist Jody D., Mary Jo Bitner and Bernard H. Booms (1985) “Identifying Communication Difficulties in the Service Encounter: Critical Incident Approach", in The Service Encounter, (eds. J. Czepiel, M. Solomon and C. Suprenant), p.195-212, Lexington, Massachusetts: Lexington Books.

Johnston, Robert (1995) “The Determinants of Service Quality: Satisfiers and Dissatisfiers”, International Journal of Service Industry Management, 6(5), p.53-71.

Johnston, Robert and Stefan Michel (2008) "Three Outcomes of Service Recovery: 
Customer Recovery, Process Recovery and Employee Recovery", International Journal of Operations and Production Management, 28(1), p.79-99.

Kelley, Scott W., K. Douglas Hoffman and Mark A. Davis (1993) "A Typology of Retail Failures and Recoveries", Journal of Retailing, 69(1), p.429-452.

Kula Değirmenci, Nil (2012) Çoklu Taşıma İşleticisi Olarak Taşıma İşleri Komisyoncusunun Sorumluluklarına ve Sorumluluk Sigortası Himayesine İlişkin Bir İnceleme, Izmir: Dokuz Eylul University.

Lewis, Barbara R. and Pamela McCann (2004) "Service Failure and Recovery: Evidence from the Hotel Industry", International Journal of Contemporary Hospitality Management, 16 (1), p.6-17.

Lockshin, Larry and Gordon McDougall (1998) "Service Problems and Recovery Strategies: An Examination of the Critical Incident Technique in a Business to Business Market", International Journal of Retail and Distribution Management, 26(11), p.429-438.

Lundberg, Christine (2011) "Critical Service Encounters in Hotel Restaurants: The Personnel's Perspective", Scandinavian Journal of Hospitality and Tourism, 11(1), p.1-19.

McCollough, Michael A., Leonard L. Berry and Manjit S. Yadav (2000) "An Empirical Investigation of Customer Satisfaction After Service Failure and Recovery", Journal of Service Research, 3(2), p.121-137.

Mentzer, John T., William DeWitt, James S. Keebler, Soonhong Min, Nancy W. Nix, Carlo D. Smith and Zach G. Zacharia (2001) "Defining Supply Chain Management", Journal of Business Logistics, 22(2), p.1-25.

Michel, Stefan (2001) "Analyzing Service Failures and Recoveries: a Process Approach", International Journal of Service Industry Management, 12(1), p.20-33.

Mohr, Lois A. and Mary Jo Bitner (1995) "The Role of Employee Effort in Satisfaction with Service Transactions", Journal of Business Research, 32(3), p.239-252.

Oflaç, Bengü S., Ursula Y. Sullivan and Tunçdan Baltacioglu (2012) "An Attribution Approach to Consumer Evaluations in Logistics Customer Service Failure Situations", Journal of Supply Chain Management, 48(4), p.51-71.

Ozgen, Ozge and Sumeyra Duman Kurt (2012) "Pre-recovery and Post-recovery Emotions in the Service Context: A Preliminary Study", Managing Service Quality: An International Journal, 22(6), p.592-605. 
Panayides, Photis M. and Meko So (2005) “The Impact of Integrated Logistics Relationships on Third-Party Logistics Service Quality and Performance", Maritime Economics \& Logistics, 7(1), p.36-55.

Parasuraman, Arun, Valarie A. Zeithaml and Leonard L. Berry (1991) "Refinement and Reassessment of the SERVQUAL Scale", Journal of Retailing, 67(4), p.420.

Parasuraman, Arun, Valarie A. Zeithaml and Leonard L. Berry (1993) "The Nature and Determinants of Customer Expectations of Service", Journal of the Academy of Marketing, 21(1), p.1-12.

Qureshi, M. N., Dinesh Kumar and Pradeep Kumar (2007) "Modeling the Logistics Outsourcing Relationship Variables to Enhance Shippers' Productivity and Competitiveness in Logistical Supply Chain", International Journal of Productivity and Performance Management, 56(8), p.689-714.

Smith, Amy K., Ruth N. Bolton and Janet Wagner (1999) "A Model of Customer Satisfaction with Service Encounters Involving Failure and Recovery", Journal of Marketing Research, p.356-372.

Stauss, Bernd (1993) "Service Problem Deployment: Transformation of Problem Deployment into Problem Prevention Activities", International Journal of Service Industry Management, 4(2), p.41-62.

Stauss, Bernd and Bernhard Weinlich (1997) "Process-Oriented Measurement of Service Quality", European Journal of Marketing, 31(1), p.33-37.

Stewart, Gordon (1995) "Supply Chain Performance Benchmarking Study Reveals Keys to Supply Chain Excellence", Logistics Information Management, 8(2), p.38-44.

Strandvik, Tore and Maria Holmlund (2008) "How to Diagnose Business-to-Business Relationships by Mapping Negative Incidents", Journal of Marketing Management, 24(34), p.361-381.

Swanson, Scott R. and Maxwell K. Hsu (2009) "Critical Incidents in Tourism: Failure, Recovery, Customer Switching, and Word of Mouth Behaviors", Journal of Travel and Tourism Marketing, 26(2), p.180-194.

Tax, Stephen S., Stephen W. Brown and Murali Chandrashekaran (1998) "Customer Evaluations of Service Complaint Experiences: Implications for Relationship Marketing", Journal of Marketing, 61(2), p.60-76. 
Valarie A. Zeithaml, Leonard L. Berry and Ananthanarayanan Parasuraman (1996) "The Behavioral Consequences of Service Quality", The Journal of Marketing, p.31-46.

Van Doorn, Jenny and Peter C. Verhoef (2008) "Critical Incidents and the Impact of Satisfaction on Customer Share", Journal of Marketing, 72(4), p.123-142.

Zhu, Xia and Judy Zolkiewski (2015) "Exploring Service Failure in a Business-to-Business Context”, Journal of Services Marketing, 29(5), p.367-379.

Zhu, Zhen, Kumar, Sivakumar and Ananthanarayanan Parasuraman (2004) "A Mathematical Model of Service Failure and Recovery Strategies", Decision Sciences, 35(3), p.493-525. 